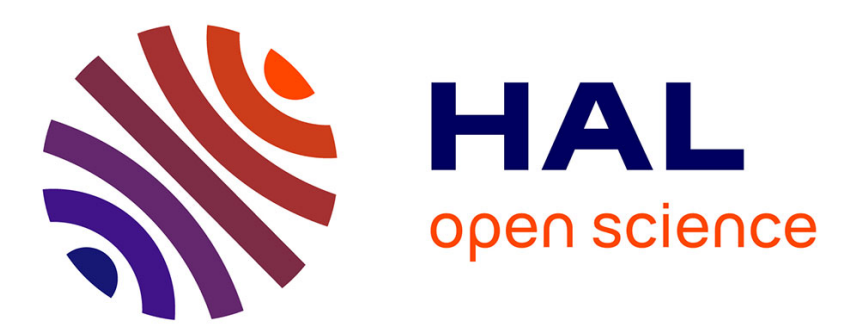

\title{
Agricultural diffuse pollution in a chalk aquifer (Trois Fontaines, France): Influence of pesticide properties and hydrodynamic constraints
}

Nicole Baran, Michel Lepiller, Christophe Mouvet

\section{- To cite this version:}

Nicole Baran, Michel Lepiller, Christophe Mouvet. Agricultural diffuse pollution in a chalk aquifer (Trois Fontaines, France): Influence of pesticide properties and hydrodynamic constraints. Journal of Hydrology, 2008, 358 (1-2), pp.56-69. 10.1016/j.jhydrol.2008.05.031 . insu-00357009

HAL Id: insu-00357009

https://hal-insu.archives-ouvertes.fr/insu-00357009

Submitted on 29 Jan 2009

HAL is a multi-disciplinary open access archive for the deposit and dissemination of scientific research documents, whether they are published or not. The documents may come from teaching and research institutions in France or abroad, or from public or private research centers.
L'archive ouverte pluridisciplinaire HAL, est destinée au dépôt et à la diffusion de documents scientifiques de niveau recherche, publiés ou non, émanant des établissements d'enseignement et de recherche français ou étrangers, des laboratoires publics ou privés. 


\title{
Agricultural diffuse pollution in a chalk aquifer (Trois Fontaines, France): Influence of pesticide properties and hydrodynamic constraints
}

\author{
N. Baran ${ }^{a}$, M. Lepiller ${ }^{b}$ and C. Mouvet ${ }^{a}$ \\ ${ }^{a}$ BRGM, 3 Avenue Claude Guillemin, BP 6009, 45060 Orléans cedex 2, France \\ ${ }^{\mathrm{b}}$ ISTO, UMR6113, CNRS/INSU Ecole Polytechnique de l'Université d'Orléans, 8 rue \\ Léonard de Vinci, 45072 Orléans cedex 2, France
}

\section{Summary}

The characterization of the transfer of pesticides to and in groundwater is essential for effective water resource management. Intensive monitoring, from October 1989 to May 2006, of a weakly karstified chalk aquifer system in a $50 \mathrm{~km}^{2}$ agricultural catchment, enabled the characterization of the temporal variability of pesticide concentrations in the groundwater of the main outlet. Atrazine and its metabolite deethylatrazine were quantified 394 and 393 times in 476 samples with concentrations ranging from the quantification limit $\left(0.025 \mu \mathrm{g} \mathrm{L}^{-1}\right)$ to 5.3 and $1.86 \mu \mathrm{g} \mathrm{L}^{-1}$, respectively. This common presence, compared to the rare detections of isoproturon (in 108 of 476 samples), the pesticide most widely used in the catchment during at least the past decade, highlighted the significant effect of pesticide properties in the time series of concentrations observed in the groundwater. The use of geochemical tracers (nitrate, chloride) analysed in the groundwater and the hydrodynamic monitoring of the system (discharge, water levels) enabled identification of various infiltration mechanisms governing the functioning of the system. The hydrodynamic study showing that the relative contribution of the infiltration mechanisms varies with time, made it possible to explain major variations observed in the pesticide-concentration time series recorded at the spring.

Keywords: Pesticides; Nitrate; Groundwater; Trend; Monitoring

\section{Introduction}

There is growing evidence of the deterioration of groundwater resources due to agricultural practices not only in North America and Europe ([Barbash et al., 2001], [EEA, 1999] and [IFEN, 2004]) but also in countries less studied until now ([Brena et al., 2005], [Singh et al., 2005], [Tariq et al., 2004] and [Thapinta and Hudak, 2003]). In some places, pesticide concentrations now exceed the European drinking-water limit of $0.1 \mu \mathrm{g} \mathrm{L}{ }^{-1}$ per substance (except for aldrin, dieldrin and heptachlor, for which the limit is $0.03 \mu \mathrm{g} \mathrm{L}^{-1}$ ). In many countries (United Kingdom, Denmark, Switzerland), drinking water is partly or dominantly supplied by groundwater, notably in France where $60 \%$ of the supply comes from aquifers. Assessing the extent of pesticide contamination in aquifer systems and understanding the transport of pesticides to groundwater is, therefore, of major importance for the management of groundwater resources (Lapworth et al., 2006).

Various spatial scales can be used for studying the transfer of pesticides. Although laboratory experiments (batch, soil columns) enable to a certain extent parameter disaggregation, they cannot take into account parameters such as spatial variability and hydrodynamic phenomena. An intermediate scale involves recreating in the laboratory, with some simplification, 
phenomena likely to be encountered in the field (undisturbed soil columns, lysimeters).

Another approach, very integrating but for which the mechanistic interpretation is difficult, is to carry out field studies at the scale of entire hydrological systems. Few published data exist at this scale concerning intensive monitoring over relatively long periods, whether at catchment outlets ([Baran et al., 2007], [Morvan et al., 2006] and [Rowden et al., 2001]) or at observation points spread over the basin ([De Guzman et al., 2005] and [Lapworth et al., 2006]). Only a few studies have been published in which both hydrogeological contexts and hydrodynamics have been taken into account ([Baran et al., 2007] and [Lapworth and Gooddy, 2006]).

Atrazine (ATR) and isoproturon (IPU) are herbicides currently detected in groundwater ([Carabias-Martinez et al., 2003], [Gooddy et al., 2001], [IFEN, 2004] and [Pucarevic et al., 2002]). The greater risk of ATR leaching compared to that of IPU has been demonstrated by comparison of sorption, volatilization and mineralization processes of both molecules in various soils ([Boivin et al., 2005] and [Mordaunt et al., 2005]). Considering ATR and IPU degradation in chalk, Johnson et al. (2000) reported that, under certain conditions, IPU can be degraded in the unsaturated and saturated zones of a chalk aquifer, whereas atrazine is never degraded. Issa and Wood (1999) also showed that the degradation rate of IPU is higher than that of ATR in the unsaturated zone of chalk. These observations might indicate that, for similar applied quantities, there is a greater risk of groundwater contamination by ATR than by IPU.

In France, the Cretaceous chalk of the Paris Basin is a major aquifer formation. Its study is also of international interest because chalk is the largest aquifer formation in England (Johnson et al., 1998). The chalk is characterized by a porous matrix (pore sizes between 0.2 and $2 \mu \mathrm{m}$ ) with a total porosity of $30-40 \%$ and a low hydraulic conductivity at saturation $\left(10^{-9}-10^{-8} \mathrm{~m} \mathrm{~s}^{-1}\right.$, Price et al., $1993 ; 1.3 \times 10^{-8} \mathrm{~m} \mathrm{~s}^{-1}$, Brouyère et al., 2004). The permeability of chalk is due largely to the presence of fissures. Although the porosity associated with the fissures is very low, their contribution to the saturated hydraulic conductivity is predominant. Price et al. (1993) reported porosity values associated with fissures of around $0.01 \%$ and saturated hydraulic conductivity values ranging between $10^{-5}$ and $10^{-3} \mathrm{~m} \mathrm{~s}^{-1}$.

According to Mathias et al. (2005), migration within the matrix is significant and cannot be disregarded, even if it is very slow $(<1 \mathrm{~m}$ per year), nor can transfer through fissures be ignored. The respective contribution of each transfer pathway remains to be determined, especially since exchanges of water and solutes between the matrix and the fractures are also involved ([Brouyère et al., 2004] and [Fretwell et al., 2005]). Contaminants can either migrate quickly along fissures or be strongly retarded in less mobile water within the matrix, depending on the degree of saturation of the chalk. The mobility and retardation of contaminants is therefore influenced by factors such as recharge conditions prevailing at the top of the chalk formation and the structural characteristics of the chalk ([Brouyère et al., 2004] and [Haria et al., 2003]).

The dissolution of the chalk that occurs preferentially in existing fissures can lead to the formation of conduits that in turn produce karst systems. Karst aquifers are known to be vulnerable because the recharge through sinkholes short-circuits the soil and the unsaturated zone and its potential for contaminant attenuation. Studies have shown that variations in nitrate concentrations in karst aquifers result not only from the temporal variability of nitrogen input but also from the various types of aquifer recharge. Toran and White (2005) demonstrated that variations of calcium and nitrate concentrations revealed types of recharge, 
recharge being a mixture of fast and slow pathways. Thus, various tools can be used for characterizing aquifer recharge. One of them is the analysis of the groundwater concentrations of chloride ([Aquilina et al., 2006] and [Ribolzi et al., 2000]), a not reactive, conservative tracer introduced by rainfall and fertiliser (Négrel and Pauwels, 2004) and which can be concentrated in soils during dry periods.

The aims of our study were to (i) monitor a chalk aquifer for several years in order to characterize the temporal variability of groundwater contamination by ATR, IPU and their metabolites; (ii) calculate annual pesticide mass balances for a period of 13 years with contrasted climatic conditions; and (iii) identify the different mechanisms influencing water and solute transfer and evaluate their impact on pesticide concentration time series. To reach these objectives, a 17-year monitoring programme in an agricultural catchment $\left(50 \mathrm{~km}^{2}\right)$ corresponding to a weakly karstified system developed in chalk (the Trois Fontaines aquifer system, France) was conducted. The programme included hydrodynamic, geochemical and pesticide measurements.

\section{Materials and methods}

\section{The hydrological system}

The boundaries of the Trois Fontaines karst hydrological system, developed in Paris Basin chalk in the eastern part of the Loiret department (France, Fig. 1), have been precisely determined by piezometric measurement campaigns (Lasne, 1992). The system, intensively characterized by Lasne (1992), has an area of around $50 \mathrm{~km}^{2}$ and two main outlets -the Trois Fontaines springs, which discharge 55\% of the total outflow, and the Moulin de Loinces springs which discharge $30-40 \%$. In addition, there are minor springs in the bed of the Cléry river. The average thickness of the unsaturated zone is about $25 \mathrm{~m}$, with a maximum of around $36 \mathrm{~m}$. The bottom of the aquifer overlies less permeable chalk. The aquifer is totally unconfined.

Morphologically, the terrain is an undulating plateau inclined slightly to the northwest and cut by dry valleys. The elevation varies between $105 \mathrm{~m}$, the elevation of the system's lowest outlet, and $184 \mathrm{~m}$.

The hydrographic network functions only intermittently. Dye tracers injected into sinkholes visually observed confirmed the existence of rapid circulation (velocity of several meters per hour) between the sinkholes and the basin's outlets. Although sinkholes were observed, no karst conduits accessible to humans were found. Indeed, the system is only weakly karstified.

Soil maps were drawn with data from 270 hand auger samples and 1000 observations of the surface layer (Baran, 1999). Three major pedological units were identified. The first, leached soil (or luvisol - FAO Classification), usually with a loamy-clayey texture and commonly hydromorphic, covers $51 \%$ of the surface of the basin, mostly in the lower part of the system. The second unit, covering $34 \%$ of the surface area, mostly in the upper part of the system, is degraded luvisol, with a tendency to crusting. The remaining $15 \%$ are rocky or alluvial and/or colluvial soils present mostly in thalwegs. 


\section{Meteorological data}

A national meteorological service rain gauge, installed in 1971 but recording comprehensive time series only since 1983, is located in the upstream part of the hydrogeological basin about $11 \mathrm{~km}$ south of the springs. The annual rainfall calculated for the hydrologic year (September to August) varied by a factor of about 2 (517.2 and 1002.1 mm for hydrologic years 1991-92 and 2000-01, respectively) during the period for which data are available (1982-2005), with an annual average of $734.6 \mathrm{~mm}$ (Fig. 2). The year 2004-05 showed a rather large water deficit after three years of near average rainfall. The estimated return periods are the inverse of the exceedance probability $(p)$ for dry years and $1 /(1-p)$ for wet years. This estimation enables to highlight the exceptional character of the 1991-92 and 2000-01 cycles, which were particularly dry and wet, respectively. Although rainfall appeared to be relatively well distributed throughout the year (monthly averages vary between 49.8 and $72.3 \mathrm{~mm}$ ), the months of September, October, November, December and May were on average wetter.

Daily potential evapotranspiration (PET) values, calculated using the Penmann-Monteih equation, were taken from the closest national meteorological station providing such data, located about $70 \mathrm{~km}$ west of the catchment. During the study period, the highest values were recorded in 1990 and 2003 (1011.4 and $952.8 \mathrm{~mm}$, respectively) and were much greater than the average for the period $(817 \mathrm{~mm})$. The lowest values (below $700 \mathrm{~mm}$ ) were recorded, in increasing order, in 1981, 1979, 1978, 1987, 1980, 1988.

\section{Discharge measurements and piezometric heads}

The discharge at the main spring was continuously measured from January 1989 to December 1999, November 2000 to December 2003 and July 2004 to May 2006 (Fig. 3). The gaps were caused by various technical problems. The on-line continuous pressure-head measurements were converted into discharge values with a calibration curve adapted for the weir. Various gauging campaigns enabled verification of the correct functioning and calibration of the sensor. The weir can be used to measure up to a maximum discharge of $198 \mathrm{~L} \mathrm{~s}^{-1}$. Beyond this value, the measurement is biased because flooding in the Cléry River, located about $100 \mathrm{~m}$ downstream from the springs, blocks outflow from the spring.

While the spring was pumped only several hours a day at the beginning of the monitoring campaign for the drinking water supply, the installation in March 2005 of a water treatment plant requiring the continuous immersion of bacterial filters led to an increase in the pumping rate. The discharge measured at the spring was corrected for these pumped volumes.

Three high density piezometric measurement campaigns (2-3 piezometers $\mathrm{km}^{-2}$ ) were done over the entire basin in February 1988, September 1990 and March-April 2003. Consequence of the variable climatic conditions, hydrodynamic contexts on these dates were very different according to piezometric data gathered manually almost every week since January 1990 at the Bissaugerie well located in the upstream part of the basin (Fig. 5).

\section{Agricultural context}

The Trois Fontaines aquifer system is located in a region of intensive agriculture with a predominance of polyculture. There are no urban or industrial point sources of pollution within the basin. About $80 \%$ of the surface area of the drainage basin is usable farm land, $12 \%$ is woods, and the remaining $8 \%$ is used for housing, roads and oil exploitation. During 
the years 1992-93 to 1996-97, a survey of farmers growing crops on around $50 \%$ of the usable farm land enabled to map land use and list the pesticides that were applied. Cereal crops, notably wheat, predominated and occupied around $50 \%$ of the cultivated surface area. Corn, rapeseed, sunflowers and fallow land each occupied about $10 \%$. The remaining $10 \%$ was planted with various crops such as onions, alfalfa, and grassland. As a direct result of the cropping system, isoproturon (IPU), a wheat herbicide, was widely used. In weight, it accounted for around $24 \%$ of all of the products used. It was followed by trifluraline, another herbicide used on wheat, as well as on rapeseed and sunflowers $(6 \%)$, and thereafter by various molecules including atrazine (ATR), a corn herbicide (5\%). A survey of other possible pesticide users such as SNCF (the French railways), municipalities, highway maintenance services, etc. showed that IPU and ATR were used solely for agricultural purposes during the period of our study.

Unfortunately, no information is available concerning the use of specific pesticides in the basin after 1997, because the presence of over 60 farmers in the basin made further data collection incompatible with the resources available for the complete study. Agricultural practices for the periods without data from interviews with farmers (1959-92, 1997-2006) were therefore estimated, based on evolutions in pesticide regulations at the national level. The maximum application rate for IPU was reduced from 1800 to $1200 \mathrm{~g} \mathrm{ha}^{-1}$ on January 1 , 2004. For ATR, the 1959 maximum application rate of $2500 \mathrm{~g} \mathrm{ha}^{-1}$ was reduced to 1500 in 1990 , and then to $1000 \mathrm{~g} \mathrm{ha}^{-1}$ in 1997 , before the use of this molecule was banned on September 1, 2003. No specific data on nitrate loads in the catchment were collected. However, data obtained at the regional scale showed that loads were quite constant during the past decade with an average bought quantities of $111 \mathrm{t}$ of nitrogen per year $( \pm 14.5 \mathrm{t})$ for 33 cropping years (1972-73 to 2004-05 - Unifa, 2007).

\section{Monitoring and analysis}

Two pesticide molecules, IPU and ATR, and several of their metabolites, monodesmethylisoproturon (MDIPU), didesmethylisoproturon (DDIPU), desethylatrazine (DEA) and desisopropylatrazine (DIA), were measured for 13 years (February 2, 1993-May $16,2006)$ in a total of 476 samples collected at an average rate of one every 10 days $( \pm 17$ days), the longest interruption occurring between June 1, 2004 and April 19, 2005. Since the monitoring period was particularly long, both extraction and analytical techniques used for determination evolved. Analyses were first done by liquid phase chromatography with diode array detector after liquid-liquid extraction, and later (since January 2005) with solid phase extraction and LC/MS/MS determination. The detection limits also evolved during the campaign but were always equal to or less than $0.05 \mu \mathrm{g} \mathrm{L}^{-1}$ for all of the molecules studied. Physico-chemicals properties of these molecules are shown in Table 1.

Chloride and nitrate ions were measured 1330 times since January 25, 1989, at average intervals of 4.75 days ( \pm 9.1 days), the highest frequency being about one sample every two days up until June 1994. Initially determined by colorimetric methods, these ions were determined by capillary electrophoresis since the end of 1992 . For both ions, the detection limit is $0.5 \mathrm{mg} \mathrm{L}^{-1}$ and the measurement precision is less than $10 \%$. 


\section{Statistical treatment}

To better understand the relationships between different variables, principal component analysis (PCA) was done using XLSTAT ${ }^{\circledR}$ software, with correlation tests using a threshold value of $\alpha=0.05$.

\section{Results and discussion}

\section{Global hydrodynamic functioning}

Various piezometric measurement campaigns enabled identification of the boundaries of the hydrogeological system and the distribution of hydraulic gradients. The hydrological system had a very marked drainage axis flowing SE-NW (Fig. 1). This differed significantly from the surface hydrographic network, which flowed for the most part $\mathrm{S}-\mathrm{N}$. The drainage axis corresponded to a zone where dissolution/karstification has increased the permeability of the chalk. The piezometric domes that indicate the boundaries of the system attested to the existence of zones that are either little or not at all karstified, and where flow is slow. The comparison of the piezometric maps obtained for three different dates that correspond to different piezometric states (based on almost continuous data gathered at the Bissaugerie well - Fig. 5) showed the temporal stability of the system's boundaries and the persistence of the drainage axis.

At the Bissaugerie well, located in the drainage axis about $8600 \mathrm{~m}$ from the Trois Fontaines springs, the greatest range in water levels measured during the study period was $17.02 \mathrm{~m}$, with a minimum level of $123.95 \mathrm{~m}$ on September 17, 1993, and a maximum of $140.97 \mathrm{~m}$ on March 14, 2002 (Fig. 5). The 1988-93 period corresponded to five consecutive deficit hydrological cycles, which explains the low levels reached in the autumn of 1993. The years 2002 and 2003, with near average rainfall, followed three wet years (1999, 2000 and $2001-2001$ being, in addition, rather exceptional with a return period of 24 years). In addition to these inter-annual cycles, annual cycles were visible with periods of low water levels in SeptemberNovember and high water levels in March-May, depending on the hydrological year. For example, the high-water period was not clearly discernible during the 1992-93 cycle due to low recharge, whereas it was well marked in 1994-95.

The observed water-level variations were correlated with discharge variations recorded at the Trois Fontaines springs where intra- and inter-annual cycles were also visible (Fig. 3). A drop in discharge rates to around $30 \mathrm{~L} \mathrm{~s}^{-1}$ in the autumn of 1993 in response to a rainfall deficit in 1988-93 was also particularly visible. The discharge then increased and was greater than $100 \mathrm{~L} \mathrm{~s}^{-1}$ until 2001-03. Within this general trend, there were also periods of lower discharge during each hydrological cycle. There were other minor, short-term variations in the average daily discharge time series. These were caused by rainy periods (e.g., June 1993), which can occur at any time during the hydrological cycle, not only when the soil is saturated. They were characterized by water flowing rapidly in the large voids (fissures and/or conduits) as a result of immediate infiltration. Such immediate infiltration, which is the rapid response of the system to a rainfall pulse, was also marked by sharp increases in chloride and nitrate concentrations caused by the inflow of water enriched in mineral anions due to evapotranspiration (Lasne, 1992) even if the volume of water corresponding to immediate infiltration is limited compared to the volume corresponding to the base-flow of the spring. As the base-flow increased during the second part of the monitoring period and the volume of immediate infiltration can be considered rather constant, the impact on discharge and water 
quality is less visible during the second part of the time series. There was, thus, both slow and rapid flow within the aquifer. Conceptually, slow infiltration corresponds to the low transmissivity-high storage part of the groundwater system while rapid flow through fissures and/or conduits that might be related to sinkholes corresponds to highly permeable parts of the aquifer formation. No physical measurements were done on site to determine the size of fissures or conduits but according to Maurice et al. (2006), fissures in chalk several millimetres wide can generate apparent velocities of several kilometres per day. The existence of such fissures is therefore conceivable and might explain the existence of rapid circulation under certain climatic conditions.

\section{Nitrate concentration time series}

Nitrate concentrations varied by a factor of 2.5 during the monitoring, from $25.7 \mathrm{mg} \mathrm{L}^{-1}$ on April 12, 1992 to $63.8 \mathrm{mg} \mathrm{L}^{-1}$ on February 27, 2003 (Fig. 3). The concentrations generally decreased between 1988 and the summer of 1992, before increasing again to their maximum values in 2001 and 2002. The general trend was similar to that of spring discharge. The discharge rates and nitrate concentrations were, indeed, significantly $(\alpha=0.05)$ positively correlated $(r=0.676 ; n=1184)$ which means that the increases in discharge associated with recharge caused a degraded water quality by increasing the nitrate content. Similar observations were made between chloride and discharge $(r=0.666)$. The very good correlation between nitrate and chloride concentrations $(r=0.992)$ confirmed the agricultural origin of the contamination, these two elements being fertilizer components (Négrel and Pauwels, 2004). At the spring, during long dry periods, nitrate concentrations generally decreased. This was probably due to the fact that a greater percentage of the discharge was relatively older groundwater from the more diffuse-flow parts of the flow system, as suggested by Rowden et al. (2001). This older water appeared to be less contaminated than the more recent water that contributes to increased discharge. Short-time variations of nitrate concentrations were also observed in accordance with flow variations (Figure 3 and Figure 4 - December 1992, February 1993, October-December 1993, etc.) as a consequence of immediate infiltration. In the present case, therefore, variations in nitrate concentration seemed to be more closely related to the hydrodynamic context than to limited changes in agricultural practices, as known at the regional scale.

\section{IPU concentration time series}

IPU concentrations of several tenths of a $\mu \mathrm{g} \mathrm{L}^{-1}$ were detected in $23 \%$ of the samples collected at the system's outlet (108 out of $476-$ Fig. 3 ). The maximum concentration was $2.32 \mu \mathrm{g} \mathrm{L}^{-1}$, measured on October 2, 1996. Such periodic IPU concentration peaks were observed by Johnson et al. (2001) in another chalk aquifer. During the present study, IPU concentrations were not correlated with discharge rates, which means that, contrary to what was observed for nitrate, something other than recharge controlled the IPU concentration.

All periods of IPU detection, usually during winter or spring, followed crop treatment, IPU being applied either at the beginning of winter or during the spring, depending on rainfall and the farmers' ability to reach their plots. The hydrological contexts during these two possible treatment periods were, however, different. Indeed, the spring applications (February-March) coinciding with the end of the aquifer recharge period, whereas winter applications (November-December) occur at the beginning of the recharge period. The existence of IPU peaks whatever the application period confirms the existence of a transfer mechanism other than and additional to the slow aquifer recharge by infiltration through the chalk matrix. 
The periods during which IPU was present at the outlet coincided in fact with periods of rapid increase in discharge, sometimes accompanied by an increase in mineral anion concentrations, which indicated immediate infiltration through rapid circulation pathways as particularly noticeable during the spring of 1993 and 1994 (Fig. 4). Up until the summer of 1995, IPU concentrations were significantly correlated with chloride and nitrate concentrations $(r=0.272$ and 0.199 , respectively). Since these two elements are markers of infiltration, their low correlations with IPU concentrations mean that a factor other than immediate infiltration governs the variations in IPU concentrations at the spring. This factor is likely to be the availability of IPU for leaching. Indeed, after application, IPU is available for leaching for only some weeks due to the onset of degradation processes and the formation of bound residues ([Perrin-Ganier et al., 1996], [Pieuchot et al., 1996] and [Walker et al., 2005]). These authors have reported that the delay between application and significant rainfall events affects the leaching losses. If, then, considering the years for which farmers have supplied data on application rates (1992-93 to 1996-97), we see that the higher IPU concentrations in 1995 than in 1993 or 1994 cannot be associated with either an increase in the quantities applied by farmers, or with a change in the total surface areas treated. The supposed particularly short intervals (compared to other years) between the winter treatment in March 1995 and the episode of immediate infiltration that followed might explain the higher concentrations. Moreover, the high flow in March-April 1995 was higher than it had been during similar periods in previous years. Greater volumes of water infiltrated during the episodes of immediate infiltration in 1995 and this water made up a larger proportion of the total discharge, which is a mixture of the rapidly infiltrating water and the springs' more slowly flowing base flow. Therefore, even if the IPU concentration in the infiltrating water was similar to what it had been during previous episodes due to similar farming practices, the greater proportion of this water in the total discharge could also explain the higher IPU concentrations during the winter of 1995 than during the high water stage in 1994.

Over the entire study period and assuming that there was no major change in the use of IPU, the location of plots treated with IPU in the catchment is also likely to affect the signal recorded at the system's outlet, that is to say the existence of peaks related to input and presenting variable amplitude. Indeed, as Johnson et al. (2001) showed, in areas where the chalk unsaturated zone is thin ( $5 \mathrm{~m}$ in their study) and low water potentials therefore exist throughout the profile during the recharge season, relatively small inputs of water will reduce the water potentials to the point where fissure flow will begin, which might lead to rapid infiltration. Haria et al. (2003) have also reported both rapid preferential flow and matrix flow processes under dry valleys, whereas on the interfluve site with the deep water table only matrix flow is observed.

The global hydrodynamic context, with both dry and wet years, must also be taken into account because it affects the dynamics of fissure functioning. Brouyère et al. (2004), carrying out tracer injections in the unsaturated zone of a chalk aquifer, demonstrated the influence of water recharge. The tracer arrival times varied by about three orders of magnitude, depending upon gradient conditions that prevailed as a consequence of the dual porosity-dual permeability of chalk. They concluded that any contaminant present in the infiltrating water thus can very rapidly reach the water table by rapid downward migration through the fissure network when the fissures are active.

Two IPU metabolites, MDIPU and DDIPU ([Kulshrestra and Mukerjee, 1986] and [Gaillardon and Sabar, 1994]), were analysed in the samples between December 1994 and May 1995 and between April 1998 and May 2006. DDIPU was never detected and MDIPU 
was detected only twice, on March 23, 1995 and on March 29, 1995 at very low concentrations of around $0.05 \mu \mathrm{g} \mathrm{L}^{-1}$. Besien et al. (2000) conducting IPU percolation tests in chalk columns ( $25 \mathrm{~cm}$ long, $10 \mathrm{~cm}$ wide) showed that IPU does not behave as a conservative tracer with, notably, a delay compared to bromide. They concluded, based on the low recovery rate of IPU compared to bromide, that IPU degrades during its transfer through the unsaturated zone but no data on metabolites were reported. Johnson et al. (2000) also showed that in certain cases, IPU could be degraded into MDIPU in chalk unsaturated or saturated zones.

In this study, the absence of DDIPU detection might be due to the fact that this product does not appear in the first stages of biodegradation, whereas the very low number of MDIPU detections, a metabolite that appears in the first stage of biodegradation in the surface layers (Alletto et al., 2006), would be due to its rapid mineralization rather than to an absence of production (Sorensen and Aamand, 2001). The almost complete absence of the two metabolites agrees with the observations of Baran et al. (2007) who, during a 5.5-year study with a monthly measurements, never detected MDIPU or DDIPU at the outlet of a basin in which IPU had been very widely used for over a decade.

\section{ATR and metabolite concentration times series}

ATR and DEA (Fig. 3) were detected much more often than IPU at the system's outlet (394 and 393 times, respectively, in the 476 samples), and at higher concentrations (up to $5.3 \mu \mathrm{g} \mathrm{L}^{-1}$ for ATR on May 20, 1994 and $1.86 \mu \mathrm{g} \mathrm{L}^{-1}$ for DEA on October 2, 1996), in spite of the fact that much less ATR than IPU (4.5-6 times less for the years 1992-93 to 1996-97, i.e., before the ATR application rate was reduced in 1997 and its use was banned in September 2003) had been applied in the watershed. DIA was detected sporadically at concentrations very near the quantification limit. These observations are in agreement with those made by Rowden et al. (2001) after studying a karst system over a period of 18 years: ATR, DEA and DIA concentrations exceeded $0.1 \mu \mathrm{g} \mathrm{L}^{-1}$ in $86 \%, 72 \%$ and $0 \%$ of their samples, respectively. Characterization of their mobility expressed as $K_{\mathrm{oc}}$ (soil organic carbon/water ratio) and persistence expressed as $\mathrm{DT}_{50}$ (time in which half of the quantity disappears), two intrinsic properties linked to their physico-chemical characteristics (Table 1) can be combined to estimate the leaching potential of the molecule according to the GUS index (Gustafson, 1989). Few studies deal with both sorption and degradation of the three molecules in the same soil or geological material, thus reducing the possibilities of comparing the results between studies. GUS indexes determined on the same materials for the three molecules simultaneously, demonstrated the greater leaching potential of DEA compared to that of ATR and DIA, though all three molecules are considered as leachers ([Bottoni et al., 1996] and [Fava et al., 2007]).

The use of the liquid-solid extraction technique since 2005 has led to a better extraction of DIA and has shown the discontinuous presence of DIA in quantities higher than the detection limit, but lower than the quantification limit of around $0.03 \mu \mathrm{g} \mathrm{L}^{-1}$ in the spring water. This is in agreement with the results obtained for various other groundwater measurement programmes in which DIA was detected less frequently than DEA or ATR ([Kolpin et al., 2000], [Kolpin et al., 2004], [Pucarevic et al., 2002], [Morvan et al., 2006] and [Rowden et al., 2001]).

The potential greater mineralization of DIA than ATR (Kruger et al., 1993) and the preferential degradation of ATR into DEA rather than into DIA (Winkelmann and Klaine, 
1991) could explain this lower frequency of DIA detection at the spring in spite of its potential aptitude for being leached.

Between 1993 and the end of 1998, the global variations in ATR concentrations seemed to be related to global variations in discharge with, notably, an increase in the ATR baseline after a period of heavy recharge that resulted in increased base-flow (Fig. 3). Thereafter, ATR concentrations generally decreased in spite of the heavy recharge and high discharge observed in 2001-03. On the other hand, the DEA concentrations generally followed the discharge variations. DEA is, in fact, significantly correlated with the discharge rate during the entire campaign $(r=0.282 ; n=385)$, whereas ATR is not.

As for IPU, some ATR peaks (e.g., May 19, 1994; April 30, 1996; May 22, 1997) seemed to be correlated with pesticide application periods (April, May) and could be explained in the same way by episodes of rapid infiltration occurring shortly after application (Figure 3 and Figure 4). Other peaks that did not coincide with application periods (e.g., October 2, 1996; January 27, 1994; December 4, 1996) showed that ATR, after a period of storage, can be leached several months later during episodes of immediate infiltration. The possible origin of this stored ATR is discussed below in next section.

The ATR baseline, characterized by long duration and low amplitude, increased between December 1994 and the spring-summer of 1995 after recharge increased. During this period, slow infiltration is likely to be predominant. Thereafter, the baseline decreased rather sharply up until the summer of 1998, then much more slowly and steadily. The ATR concentration decreased while the discharge increased until 2002-03, meaning that the water reaching the aquifer via a rather slow transfer would not have been more contaminated in ATR than the 1994-95 recharge water.

DEA, an ATR metabolite ([Muir and Baker, 1978] and [Sirons et al., 1973]) often detected in soil ([Adams and Thurman, 1991] and [Baluch et al., 1993]) and groundwater (Kolpin et al., 1998), has, like its parent molecule, been detected more systematically since the end of 1994 but, unlike ATR, with a notable increase in the baseline. DEA was also detected in peaks associated with episodes of immediate infiltration. The persistence of ATR and DEA almost three years after the last ATR application was in agreement with observations made at other sites where the quantities of ATR applied have decreased sharply (Lapworth and Gooddy, 2006) or have even been nil for several years (Baran et al., 2007). The ATR observed in the spring, not as a concentration peak but as the baseline, can therefore clearly not be related to application in that same year. Unfortunately, the actual transfer time can not be determined with the data available.

An indirection estimation of transfer time can be approached by using the DAR ratio proposed by Adams and Thurman (1991). Working on soil and the vadose zone, they demonstrated that the ratio of molar concentrations of DEA to ATR (called DAR) is proportional to the transfer time. Pasquarell and Boyer (1996), considering time series in a karst system, suggested a modified definition of the DAR* (DEA molar concentration/DEA molar concentration + ATR molar concentration) in order to get around the problem of many samples with ATR concentrations below the quantification limit. Here (Fig. 3), the extreme values 0 and 1 of DAR* (i.e., only ATR or DEA are quantified, respectively) are rare, values of 1 being preferentially observed in the second part of the time series when ATR applications were reduced and then stopped. Considering the general trend, many DAR* values are below 0.5 before 1998 and increased after this date. These observations are consistent with the flow 
variations during the monitoring period. The increase of flow rate corresponded to an increase of the diffuse recharge, the composition of which suggested a transfer time sufficient to allow degradation of ATR in soil, vadose or saturated zones. During the first part of the monitoring period, when discharge was lower, the DAR* suggested that the mean time-transfer was shorter and degradation shortened. Besides the general trend, short-time variations of DAR* were also observed and especially values equal to 0 in relation with the ATR application periods (springs 1994, 1995, 1997, 1998 and 1999) suggesting that rapid infiltration of water and ATR occurred from the soil to the outlet of the system a few days or weeks after the application.

The ATR degradation could theoretically take place in soil ([Adams and Thurman, 1991] and [Baluch et al., 1993]) or the vadose zone (Issa and Wood, 1999). Studies of biodegradation in saturated zones are rare. Johnson et al. (2000) showed that ATR is not degraded in a saturated zone of the chalk aquifer and Pearson et al. (2006) concluded that there was no acclimatized bacterial community featuring positive ATR degraders within a chalk aquifer known to be contaminated by ATR at concentrations varying between 0.02 and $0.2 \mu \mathrm{g} \mathrm{L}^{-1}$. Kristensen et al. (2001) demonstrated that the mineralization of aged atrazine in aquifer chalk with inoculated bacteria known to mineralize ATR was reduced with increasing residence time of ATR. As no specific experiments were done for this study, it is not possible to conclude on the respective contribution of each compartment (soil, vadose and saturated zones) to ATR degradation.

\section{Calculation of fluxes at the outlet of the basin}

The daily outfluxes of solute $F_{\mathrm{d}}$ were calculated in the following way:

Fd dlg d_1P $1 / 4 \mathrm{Cd}_{-} \mathrm{Qd}$

where $C_{\mathrm{d}}$ is the concentration measured at the spring on day $d$ or linearly interpolated between two measured values $\left(\mu \mathrm{g} \mathrm{L}^{-1}\right)$. When the measured concentration is below the detection limit, $C_{\mathrm{d}}$ is considered to be equal to the detection limit divided by 2 (Farnham et al., 2002). $Q_{\mathrm{d}}$ is the mean daily stream flow measured at the weir $\left(\mathrm{L} \mathrm{d}^{-1}\right)$.

Cumulative fluxes were calculated for hydrologic years. Unfortunately, the fluxes could not be estimated for all years because there are gaps in the discharge data (e.g., 2000-01 and 2003-04) and/or solute data (1991-92 and 2004-05 for nitrate and 1999-2000 and 2004-05 for pesticides). The nitrate and pesticide output fluxes are therefore available for only nine years, although data for discharge and nitrate (the first two parameters to be measured) are available for 17 hydrological cycles. The quantities of nitrate flowing out of the system at the springs varied by a factor of almost 3, from $54 \mathrm{t}(1992-93)$ to $141 \mathrm{t}(1998-99)$ - a factor that is assumed to be far greater than a potential increase in the quantity of nitrogen applied. This hypothesis agrees with the data available on nitrogen sales for the region.

On the other hand, although the input rate of pesticides is not precisely known, it is possible to calculate the mass balance of input and output rates for the system for a given hydrological year. For ATR, the cumulated flux of ATR+DEA at the system's outlet varies between $469 \mathrm{~g}$ (1993-94) and $915 \mathrm{~g}$ (1996-97), which represents $0.26 \%$ and $0.57 \%$ of the reported input for these years, respectively. These values are surely overestimated because it is probable that some input was not taken into account since only $50-60 \%$ of the basin's farmers provided 
information on pesticide practices. Indeed, no extrapolation of the data was made to cover the whole catchment.

Since the ATR detected in any given year actually resulted from inputs during previous years as demonstrated by the continuous detection of ATR almost three years after the last ATR applications, an estimation of the output rate based on average practices could be more reliable. Considering a surface area of 250 ha of corn treated with $1500 \mathrm{~g} \mathrm{ha}^{-1}$, the annual minimum and maximum output rates of ATR + DEA would represent between $0.11 \%$ and $0.24 \%$ of the quantity of ATR applied.

Considering that the Trois Fontaines springs represent about $50 \%$ of the total discharge and assuming that the water flowing through the other outlets is of similar quality (Lasne, 1992), the output rate for ATR and DEA remains low - less than $0.5 \%$ of the average quantities applied annually. These fluxes are similar to those commonly measured below the root zone (Flury, 1996).

For IPU, regardless of the year considered, the output rate at the springs represented less than $0.03 \%$ of the quantities applied and therefore less than $0.06 \%$ on the system-scale, a value much lower than the $0.2 \%$ of applied mass obtained as a worst-case in a field-measured estimate of IPU loading to a shallow unconfined chalk aquifer (Haria et al., 2003) but similar to the $0.02 \%$ estimated by Morvan et al. (2006).

\section{Characterization of recharge water}

In order to characterize the composition of the infiltrating water, the principle of mass conservation to ion fluxes was applied. According to this principle, $Q C=Q_{1} C_{1}+Q_{2} C_{2}$ where $Q$ is the discharge at the spring, $C$ is the ion concentration measured at the spring, $Q_{1}$ is the base flow (taken as $45 \mathrm{~L} \mathrm{~s}^{-1}$, lowest values observed during the whole study period), $Q_{2}$ is the part of the total discharge associated with recharge (with $Q=Q_{1}+Q_{2}$ ), $C_{1}$ is the ion concentration in the base flow water and $C_{2}$ is the ion concentration in the recharge water. Considering that the two reservoirs (base flow water and recharge water) mix perfectly, the equation $C=\left(Q_{1}\left(C_{1}-C_{2}\right)\right) / Q+C_{2}$ is a straight line of the type $a x+b$. This simple mixing model of two reservoirs was tested for the different solutes measured at the spring. When considering average nitrate concentrations and the inverse of the average discharge per hydrological year (calculated arithmetically even though some data are missing), a significant correlation $(r=-0.86 ; n=17)$ was obtained, which confirms the hypothesis that the water drained at the outlet of the system corresponded to an almost perfect mixing of two reservoirs. This approach also enabled estimating the nitrate concentration in the infiltrating water to be around $68 \mathrm{mg} \mathrm{L}^{-1}$. A significant correlation $(r=-0.87 ; n=13)$ was also found for average DEA concentrations and the inverse of the average discharge again suggesting that the DEA concentrations observed at the spring correspond to a mixing between two reservoirs. Following the scheme, the DEA concentrations of the infiltrating water were estimated at around $0.21 \mu \mathrm{g} \mathrm{L}^{-1}$. However, no correlation was found between $l / Q$ and the ATR or IPU concentrations, suggesting that the hypothesis of the mixing of two reservoirs is not relevant for these compounds. This suggests that, contrary to nitrate and DEA, the infiltrating water has highly variable ATR and IPU concentrations over time, a variability that might be related to occurrences of temporally isolated agricultural inputs and to variability over time of degradation and the formation of bound residues, notably for IPU as discussed above. This indicates that a more complex model of mixing of two reservoirs must be probably involved for the two parent compounds. 
The calculation presented above is highly theoretical since it is done for all of the years using an arithmetic average due to data gaps. However, it leads to a strong indication of the contribution of a reservoir with a relatively stable (during decades) quality as concerns nitrate and DEA. Assuming that no factor (radical change in farming practices, for example) would appear, this is an important observation in order to predict the evolution of water quality. Indeed, maximum nitrate and DEA concentrations might not have been reached and could actually be as high as around $68 \mathrm{mg} \mathrm{L}^{-1}$ and $0.2 \mu \mathrm{g} \mathrm{L}^{-1}$, respectively. These would be "average" concentrations, to which the concentration peaks associated with immediate infiltration, which we can neither predict nor quantify, would be added. This prediction might represent a worst-case for DEA to the extent that the absence of ATR input since 2003 should lead, in the coming years, to diminishing quantities of DEA transiting through or able to be mobilized in the unsaturated and saturated zones. Allowing that, as opposed to what occurs in the soil, nitrate and pesticides are not (or usually to a very limited extent) transformed below the root zone and that slow infiltration concerns only a small volume of chalk each year, the quantity of nitrate and DEA stored in the unsaturated zone would be relatively constant over a period of several years. The localization and quantification of solutes (nitrate, ATR, DEA) reservoirs and the conditions required for their remobilization remain to be determined. Indeed, although it is evident that soils constitute a large reservoir for nitrate and some pesticides, they might not be the only reservoir. The evidence that nitrate is stored in the unsaturated zone and that some of it migrates slowly through the matrix was previously demonstrated but no evidence has yet been reported of pesticides stored in the unsaturated zone. Johnson et al. (2001) detected IPU only down to a depth of $1.3 \mathrm{~m}$ in chalk two years after application. Theories suggested to explain the absence of detection in deeper levels include the lack of penetration of IPU in the chalk matrix, migration accompanied by in situ degradation, and the presence of IPU at quantities below the detection limit of the extraction and analytical methods used. The last hypothesis has also been suggested by Brouyère et al. (2004), who did not detect any lenacil $\left(<5 \mu \mathrm{g} \mathrm{kg}{ }^{-1}\right)$ below a depth of $0.5 \mathrm{~m}$ in chalk underlying loess despite the fact that it is used every year.

The remobilization of solutes could also concern the seasonally unsaturated zone - the part of the unconfined aquifer that lies between the highest and lowest groundwater levels. Indeed, Fretwell et al. (2005) showed in a chalk system that when the water table rises to a level rich in solutes (chloride, chlorinated hydrocarbons), the solutes are remobilized. Fissures become saturated and under the effect of concentration gradients, solutes pass from the matrix to the groundwater. In the present case, where the piezometric variation at the Bissaugerie well was $17 \mathrm{~m}$, this seasonally unsaturated zone might have contributed to the remobilization of solutes, assuming that the water table rose sufficiently to reach to depths that were contaminated by the solutes migrating in the matrix by convection-dispersion processes.

The remobilization of solutes would therefore be a result of two mechanisms. The pesticides could be mobilized and transported from the soil and unsaturated zone by rapid by-pass flow through the unsaturated and saturated zones when the fissures are active, or the rising groundwater levels could leach the pollutants from the seasonally unsaturated zone. Both mechanisms might also be involved (Lapworth and Gooddy, 2006). The contribution of each of these two mechanisms probably varies temporally depending on the weather and spatially depending on the location within the basin (i.e., the thickness of the unsaturated zone). 


\section{Conclusion}

The Trois Fontaines aquifer system was monitored in terms of discharge and piezometric level over a period of 17 hydrological cycles, with the concentrations of various pesticides at the system's main outlet being determined every 10 days, on average, since 1993. Time series of pesticide concentrations at the system's outlet were different and highly variable over time for each pesticide. The phenylurea IPU, the most widely used pesticide, was detected less often than ATR (which has not been used since 2003) and its metabolite DEA. These variable detection frequencies highlight the significant effect of pesticide properties on groundwater contamination.

Less than $0.6 \%$ of the applied quantities of ATR and IPU left the basin annually, even when their main metabolites were included in mass balance calculations. This low output rate, similar to the flux of pesticides commonly measured at the bottom of the root zone, nevertheless caused intermittent exceedance of the European guideline value for drinking water $\left(0.1 \mu \mathrm{g} \mathrm{L}^{-1}\right)$.

The quality of the water at the system's outlet resulted from a mixing of waters of different composition and origin. The study of the hydrodynamic functioning of the system based on discharge time series, piezometric monitoring, and the use of nitrate and chloride tracers enabled us to identify the different infiltration mechanisms that combine and transport these different waters. The variable contribution of each of these waters depending on the weather partly explained the variable groundwater quality at the spring. While the pesticide concentrations were relatively constant during periods of low flow, episodes of rapid infiltration can lead to a rapid and short-term increase in discharge accompanied by a significant increase in pesticide concentrations, provided that the latter are available for leaching. Such peaks could be seen for the two pesticides during the weeks following their application. When dry years were followed by wet years, there was an increase in base flow from the spring, accompanied by an increase in ATR and DEA concentrations, a sign that these molecules also infiltrated more slowly through the porous matrix than through the fissures.

Pesticide-concentration time series at the spring appeared, therefore, to be controlled by both water transport mechanisms and pesticides properties. Long-term monitoring that included periods of both water deficit and recharge made it possible to identify, although not quantify at the basin scale, the role of each factor and explain the observed variations in concentrations. The interpretation of data observed at the basin's outlet and the prediction of the evolution of groundwater quality will only be possible if the transfer of the water and solutes is understood. These aspects are particularly relevant to explain and predict groundwater quality trends, aspects that should be taken into account by the European Ground Water Directive.

\section{Acknowledgements}

This study was carried out within the framework of research projects funded by the Centre Region (doctoral studies of E. Lasne and N. Baran), the Seine-Normandie and Loire-Bretagne Water Agencies and the French Ministries of the Environment and Research through BRGM research funds. The authors pay tribute to Dr. Lepiller who was one of the initiators of the monitoring project and, unfortunately, did not live to see its completion in the form of the present paper. The authors thank the water company tapping the spring, the farmers in the 
basin and all of the BRGM staff who contributed to data collection, and the BRGM Translation Unit for editing the English.

\section{References}

Adams and Thurman, 1991 C.D. Adams and M. Thurman, Formation and transport of deethylatrazine in the soil and vadose zone, J. Environ. Qual. 20 (1991), pp. 540-547.

Alletto et al., 2006 L. Alletto, Y. Coquet, P. Benoit and V. Bergheaud, Effects of temperature and water content on degradation of isoproturon in three soil profiles, Chemosphere 64 (2006), pp. 1053-1061.

Aquilina et al., 2006 L. Aquilina, B. Ladouche and N. Dörfliger, Water storage and transfer in the epikarst of karstic systems during high flow periods, J. Hydrol. 327 (2006), pp. 472-485.

Baluch et al., 1993 H.U. Baluch, L. Somasundaram, R.S. Kanwar and J.R. Coats, Fate of major degradation products of atrazine in Iowa soils, J Environ. Sci. Heal. B 28 (1993), pp. 127-149.

Baran, 1999 Baran, N., 1999. Transit de l'isoproturon et de l'atrazine dans un système hydrologique karstique de la craie (Gâtinais-France): de la station pédologique expérimentale à l'échelle du système. Documents BRGM 284, Editions BRGM. Thesis, 329p.

Baran et al., 2007 N. Baran, C. Mouvet and P. Négrel, Hydrodynamic and geochemical constraints on pesticide concentrations in the groundwater of an agricultural catchment (Brévilles, France), Environ. Pollut. 148 (2007), pp. 729-738.

Barbash et al., 2001 J.E. Barbash, G.P. Thelin, D.W. Kolpin and R.J. Gilliom, Major herbicides in ground water: Results from the national water-quality assessment, J. Environ. Qual. 30 (2001), pp. 831-845.

Besien et al., 2000 T.J. Besien, R.J. Williams and A.C. Johnson, The transport and behaviour of isoproturon in unsaturated chalk cores, J. Contamin. Hydrol. 43 (2000), pp. 91-110.

Boivin et al., 2005 A. Boivin, R. Cherrier and M. Schiavon, A comparison of five pesticides adsorption and desorption processes in thirteen contrasting field soils, Chemosphere $\mathbf{6 1}$ (2005), pp. 668-676

Bottoni et al., 1996 P. Bottoni, J. Keizer and E. Funari, Leaching indices of some major triazine metabolites, Chemosphere 32 (1996), pp. 1401-1411.

Brena et al., 2005 B.M. Brena, L. Arellano, C. Rufo, M.S. Last, J. Montano, Z. Egana Cerni, G. Gonzalez-Sapienza and J.A. Last, ELISA as an affordable methodology for monitoring groundwater contamination by pesticides in low-income countries, Environ. Sci. Technol. 39 (2005), pp. 3896-3903.

Brouyère et al., 2004 S. Brouyère, A. Dassargues and V. Hallet, Migration of contaminants through the unsaturated zone overlying the Hesbaye chalky aquifer in Belgium: a field investigation, J. Contamin. Hydrol. 72 (2004), pp. 135-164 
Carabias-Martinez et al., 2003 R. Carabias-Martinez, E. Rodriguez-Gonzalo, E. FernandezLaespada, L. Calvo-Seronero and F.J. Sanchez-San Roman, Evolution over time of the agricultural pollution of waters in an area of Salamanca and Zamora (Spain), Water Res. 37 (2003), pp. 928-938.

De Guzman et al., 2005 N.P. De Guzman, P. Hendley, D.I. Gustafson, I. van Wesenbeeck, A.J. Klein, J.D. Fuhrman, K. Travis, N.D. Simmons, W.E. Teskey and R.B. Durham, The acetochlor registration partnership state ground water monitoring program, J. Environ. Qual. 34 (2005), pp. 793-803.

EEA, 1999 EEA, 1999. Groundwater quality and quantity in Europe. Technical Report, Copenhagen, 112p.

Farnham et al., 2002 I.M. Farnham, A.K. Singh, K.J. Stetzenbach and K.H. Johannesson, Treatment of nondetects in multivariate analysis of groundwater geochemistry data, Chemometr. Intell. Lab. 60 (2002), pp. 265-281.

Fava et al., 2007 L. Fava, M.A. Orrù, S. Scardala and E. Funari, Leaching potential of carbamates and their metabolites and comparison with triazines, Microchem. J. 86 (2007), pp. 204-208.

Flury, 1996 M. Flury, Experimental evidence of transport of pesticides through field soils - a review, J. Environ. Qual. 25 (1996), pp. 25-45.

Footprint, 2006 FOOTPRINT, 2006. The FOOTPRINT Pesticide Properties DataBase. Database collated by the University of Hertfordshire as part of the EU-funded FOOTPRINT project (FP6-SSP-022704).

Fretwell et al., 2005 B.A. Fretwell, W.G. Burgess, J.A. Barker and N.L. Jefferies, Redistribution of contaminants by a fluctuating water table in a micro-porous, double porosity aquifer: field observations and model simulations, J. Contamin. Hydrol. 78 (2005), pp. 27-52.

Gaillardon and Sabar, 1994 P. Gaillardon and M. Sabar, Changes in concentrations of isoproturon and its degradation products in soil and soil solution during incubation at two temperatures, Weed Res. 34 (1994), pp. 243-250.

Gooddy et al., 2001 D.C. Gooddy, J.P. Bloomfield, P.J. Chilton, A.C. Johnson and R.J. Williams, Assessing herbicide concentrations in the saturated and unsaturated zone of a chalk aquifer in Southern England, Groundwater 39 (2001), pp. 262-271.

Gustafson, 1989 D.I. Gustafson, Groundwater ubiquity score: a simple method for assessing pesticide leachability, Environ. Toxicol. Chem. 8 (1989), pp. 339-357.

Haria et al., 2003 A.H. Haria, M.G. Hodnett and A.C. Johnson, Mechanisms of groundwater recharge and pesticide penetration to a chalk aquifer in southern England, J. Hydrol. 275 (2003), pp. 122-137

IFEN, 2004 IFEN, 2004. Les pesticides dans les eaux - Sixième bilan annuel - données 2002. Collection Etudes et travaux, $\mathrm{n}^{\circ}$ 42, Ifen, Orléans, 32 p, ISBN: 2-911089-70-7 (detailed results on CD-Rom). 
Issa and Wood, $1999 \mathrm{~S}$. Issa and M. Wood, Degradation of atrazine and isoproturon in the unsaturated zone: a study from Southern England, Pest. Sci. 55 (1999), pp. 539-545

Johnson et al., 1998 A.C. Johnson, C.D. Hughes, R.J. Williams and P.J. Chilton, Potential for aerobic isoproturon biodegradation and sorption in the unsaturated and saturated zones of a chalk aquifer, J. Contamin. Hydrol. 30 (1998), pp. 281-297.

Johnson et al., 2000 A.C. Johnson, C. White and C.L. Bhardwaj, Potential for isoproturon, atrazine and mecoprop to be degraded within a chalk aquifer system, J. Contamin. Hydrol. 44 (2000), pp. 1-18.

Johnson et al., 2001 A.C. Johnson, T.J. Besien, C.L. Bhardwaj, A. Dixon, D.C. Gooddy, A.H. Haria and C. White, Penetration of herbicides to groundwater in an unconfined chalk aquifer following normal soil applications, J. Contamin. Hydrol. 53 (2001), pp. 101-117.

Kristensen et al., 2001 G.B. Kristensen, H. Johannesen and J. Aamand, Mineralization of aged atrazine and mecoprop in soil and aquifer chalk, Chemosphere 45 (2001), pp. 927-934.

Kulshrestra and Mukerjee, 1986 G. Kulshrestra and S.K. Mukerjee, The photochemical decomposition of the herbicide isoproturon, Pest. Sci. 17 (1986), pp. 489-494.

Kolpin et al., 1998 D.W. Kolpin, J.E. Barbash and R.J. Gilliom, Occurrence of pesticides in shallow groundwater of the United States: initial results from the national water-quality assessment program, Environ. Sci. Technol. 32 (1998), pp. 558-566.

Kolpin et al., 2000 D.W. Kolpin, E.M. Thurman and S.M. Linhart, Finding minimal herbicide concentrations in ground water? Try looking for their degradates, Sci. Total Environ. 248 (2000), pp. 115-122

Kolpin et al., 2004 D.W. Kolpin, D.J. Schnoebelen and E.M. Thurman, Degradates provide insight to spatial and temporal trends of herbicides in ground water, Ground Water 4 (2004), pp. 601-608.

Kruger et al., 1993 E.L. Kruger, R.S. Somasundaram, R.S. Kanway and J.R. Coats, Persistence and degradation of ${ }^{14} \mathrm{C}$ atrazine and ${ }^{14} \mathrm{C}$ deisopropylatrazine as affected by soil depth and moisture conditions, Environ. Toxicol. Chem. 12 (1993), pp. 1959-1967.

Lapworth et al., 2006 D.J. Lapworth, D.C. Gooddy, M.E. Stuart, P.J. Chilton, G. Cachandt, M. Knapp and S. Bishop, Pesticides in groundwater: some observations on temporal and spatial trends, Water Environ. J. 20 (2006), pp. 55-64.

Lapworth and Gooddy, 2006 D.J. Lapworth and D.C. Gooddy, Source and persistence of pesticides in a semi-confined chalk aquifer of southeast England, Environ. Pollut. 144 (2006), pp. 1031-1044.

Lasne, 1992 Lasne, E., 1992. Etude du système hydrologique karstique des sources des Trois Fontaines (Saint-Loup de Gonois, Loiret). Contribution à la connaissance de la structure, du fonctionnement et de l'évolution de l'aquifère crayeux du Gâtinais (Sud est du Bassin de Paris). Thesis. 
Mathias et al., 2005 S.A. Mathias, A.P. Butler, N. McIntyre and H.S. Wheater, The significance of flow in the matrix of the Chalk unsaturated zone, J. Hydrol. 310 (2005), pp. $62-77$

Maurice et al., 2006 L.D. Maurice, T.C. Atkinson, J.A. Barker, J.P. Bloomfiled, A.R. Farrant and A.T. Williams, Karstic behaviour of groundwater in the English Chalk, J. Hydrol. 330 (2006), pp. 63-70.

Mordaunt et al., 2005 C.J. Mordaunt, B. Gevao, K.C. Jones and K.T. Semple, Formation of non-extractable pesticide residues: observations on compound differences, measurement and regulatory issues, Environ. Pollut. 133 (2005), pp. 25-34.

Morvan et al., 2006 X. Morvan, C. Mouvet, N. Baran and A. Gutierrez, Pesticides in the groundwater of a spring draining a sandy aquifer: temporal variability of concentrations and fluxes, J. Contamin. Hydrol. 87 (2006), pp. 176-190.

Muir and Baker, 1978 D.C.G. Muir and B.E. Baker, The disappearance and movement of three triazine herbicides and several of their degradation products in soil under field conditions, Weed Res. 18 (1978), pp. 111-120.

Négrel and Pauwels, 2004 P. Négrel and H. Pauwels, Interaction between different groundwaters in Brittany catchments (France): characterizing multiple sources through strontium- and sulphur isotope tracing, Water Air Soil Pollut. 151 (2004), pp. 261-285

Pasquarell and Boyer, 1996 G.C. Pasquarell and D.G. Boyer, Herbicides in karst groundwater in southeast West Virginia, J. Environ. Qual. 25 (1996), pp. 755-765.

Pearson et al., 2006 R. Pearson, A. Godley and E. Cartmell, Investigating the in situ degradation of atrazine in groundwater, Pest. Manag. Sci. 62 (2006), pp. 299-306.

Perrin-Ganier et al., 1996 C. Perrin-Ganier, C. Breuzin, J.M. Portal and M. Shiavon, Availability and persistence of IPU under field and laboratory conditions, Ecotox. Environ. Safe. 35 (1996), pp. 226-230.

Pieuchot et al., 1996 M. Pieuchot, C. Perrin-Ganier, J.M. Portal and M. Schiavon, Study of the mineralization and degradation of IPU in three soils, Chemosphere 33 (1996), pp. 467478.

Price et al., 1993 M. Price, R.A. Downing and W.M. Edmunds, The chalk as an aquifer. In: R.A. Downing, M. Price and G.P. Jones, Editors, The Hydrogeology of the Chalk of NorthWest Europe, Oxford University Press, New York (1993), pp. 35-58.

Pucarevic et al., 2002 M. Pucarevic, R. Sovljanski and N. Marjanovic, Atrazine in ground water of Vojvodina province, Water Res. 36 (2002), pp. 5120-5126.

Ribolzi et al., 2000 O. Ribolzi, P. Andrieux, V. Valles, R. Bouzigues, T. Bariac and M. Voltz, Contribution of groundwater and overland flows to storm flow generation in a cultivated Mediterranean catchment. Quantification by natural chemical tracing, J. Hydrol. 233 (2000), pp. 241-257. 
Rowden et al., 2001 R.D. Rowden, H. Liu and R.D. Libra, Results from the Big Spring basin water quality monitoring and demonstration projects, Iowa, USA, Hydrogeol. J. 9 (2001), pp. 487-497.

Singh et al., 2005 K.P. Singh, A. Malik, D. Mohan and S. Sinha, Persistent organochlorine pesticide residues in alluvial groundwater aquifers of Gangetic Plains, India, Bull. Environ. Contam. Toxicol. 74 (2005), pp. 162-169.

Sirons et al., 1973 G.J. Sirons, R. Frank and T. Sawyer, Residues of atrazine, cyanazine and their phytotoxic metabolites in a clay loam, J. Agric. Food Chem. 21 (1973), pp. 1016-1020.

Sorensen and Aamand, $2001 \mathrm{~S}$. Sorensen and J. Aamand, Biodegradation of the phenylurea herbicide isoproturon and its metabolites in agricultural soils, Biodegradation 12 (2001), pp. 69-77.

Tariq et al., 2004 M.I. Tariq, S. Afzal and I. Hussain, Pesticides in shallow groundwater of Bahawalnagar, Muzafargarh, D.G. Khan and Rajan Pur districts of Punjab, Pakistan, Environ. Int. 30 (2004), pp. 471-479.

Thapinta and Hudak, 2003 A. Thapinta and P.F. Hudak, Use of geographic information systems for assessing groundwater pollution potential by pesticides in central Thailand, Environ. Int. 29 (2003), pp. 87-93.

Toran and White, 2005 L. Toran and W.B. White, Variation in nitrate and calcium as indicators of recharge pathways in Nolte Spring, PA, Environ. Geol. 48 (2005), pp. 860-864. Unifa, 2007 Unifa (Union des Industries de la Fertilisation), 2007.

Walker et al., 2005 A. Walker, M.S. Rodriguez-Cruz and M.J. Mitchell, Influence of ageing of residues on the availability of herbicides for leaching, Environ. Pollut. 133 (2005), pp. 4351 .

Winkelmann and Klaine, 1991 D.A. Winkelmann and S.J. Klaine, Degradation and bound residue formation of atrazine in a western Tenessee soil, Environ. Toxicol. Chem. 10 (1991), pp. 335-345. 


\section{Figures}

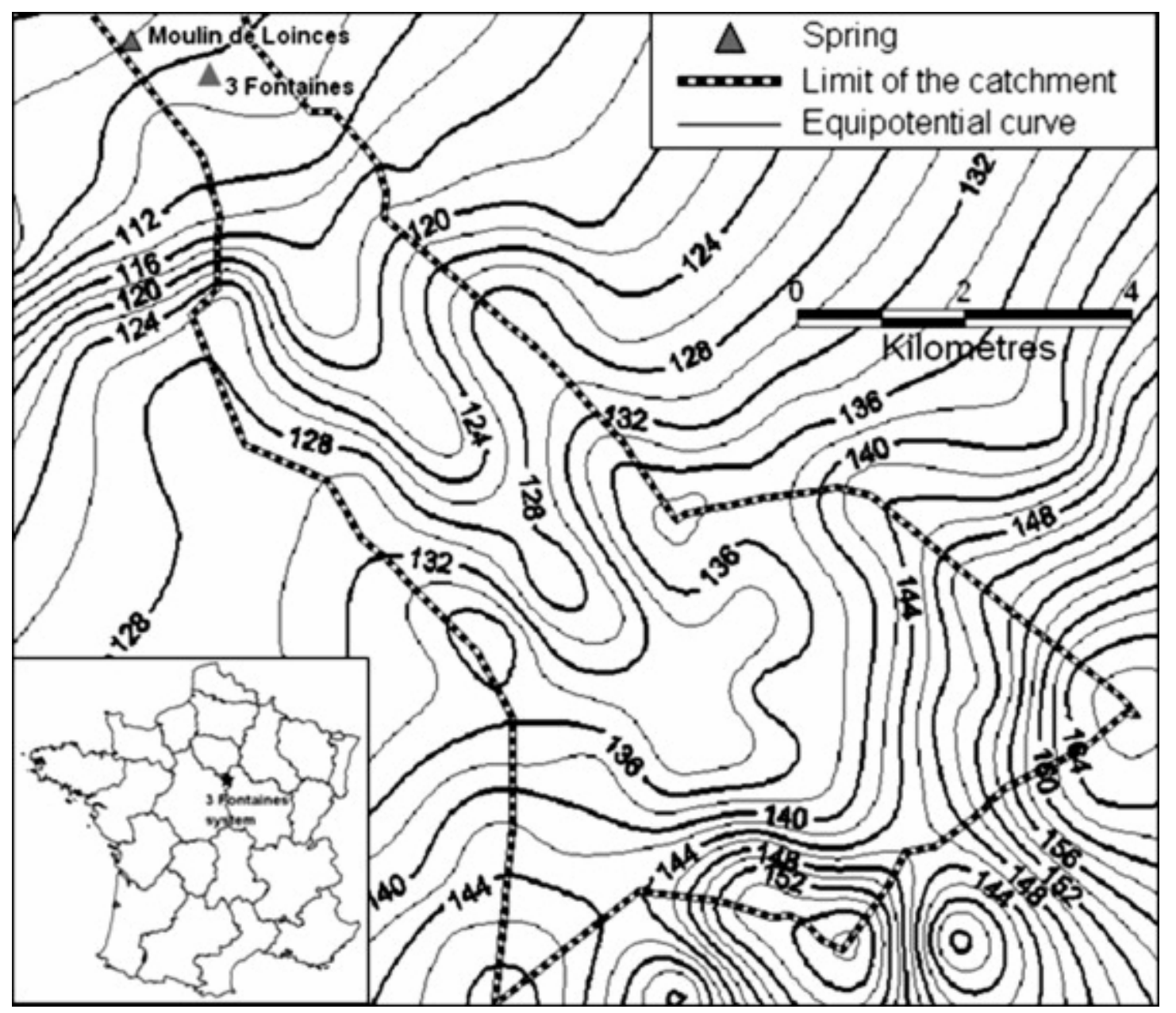

Figure 1. Location of the Trois Fontaines karst aquifer and piezometric map (September 1990).

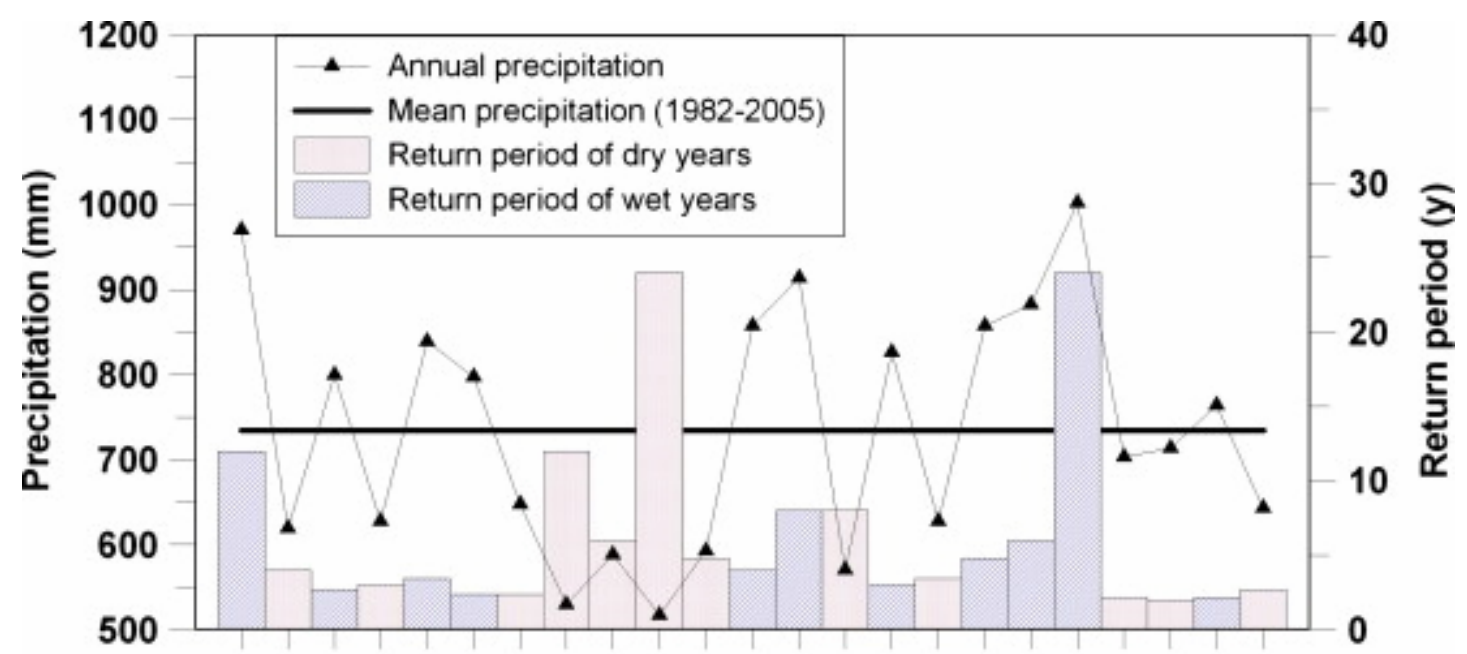

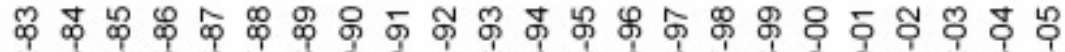
恕 \%

Figure 2. Precipitations during the period 1982-2005. 

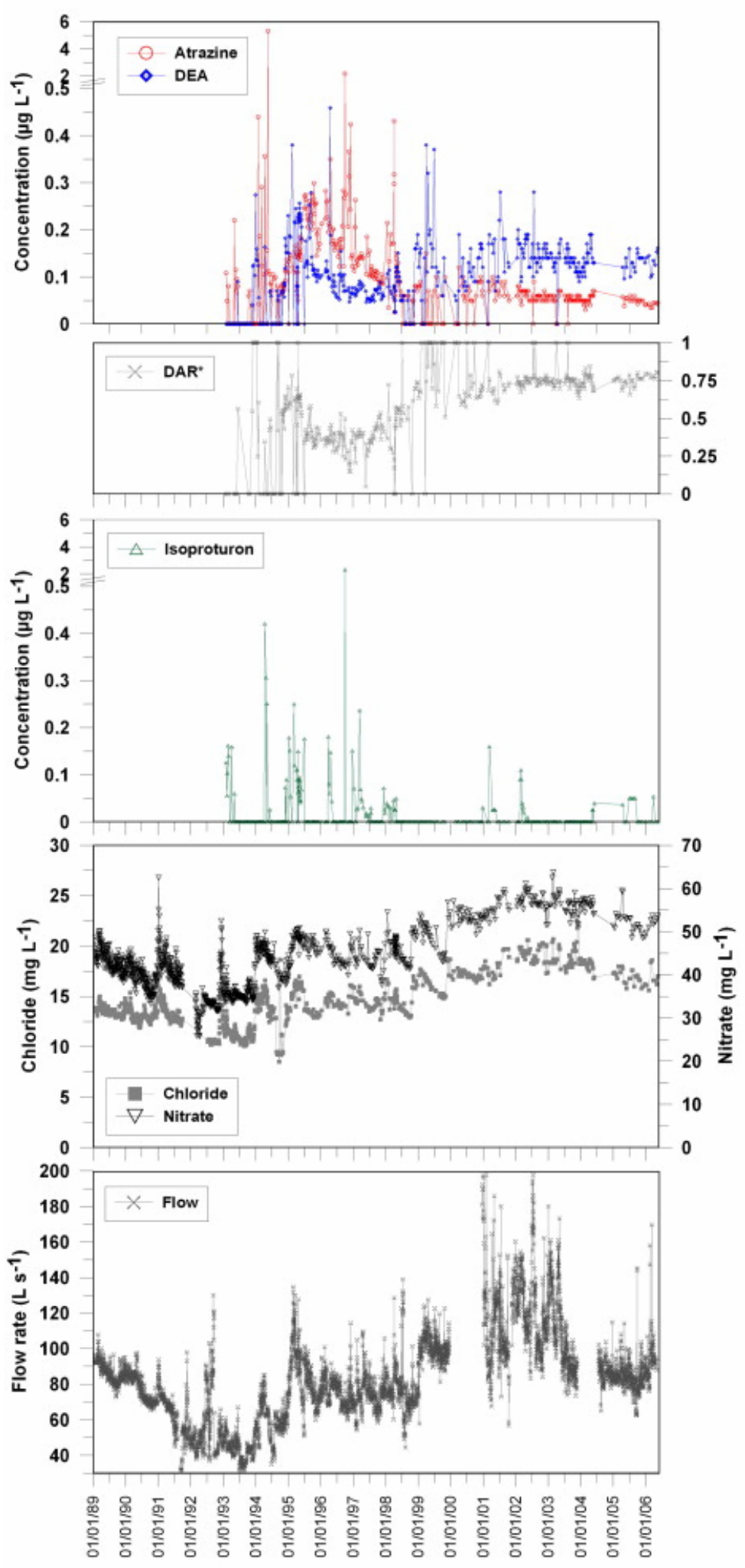

Figure 3. Time series of atrazine, deethylatrazine (DEA), modified deethylatrazine/atrazine ratio (DAR*), isoproturon, chloride and nitrate, and flow rate at the Trois Fontaines Spring from January 1989 till May 2006. (Pesticide concentrations below the quantification limit are represented equal to 0 .) 


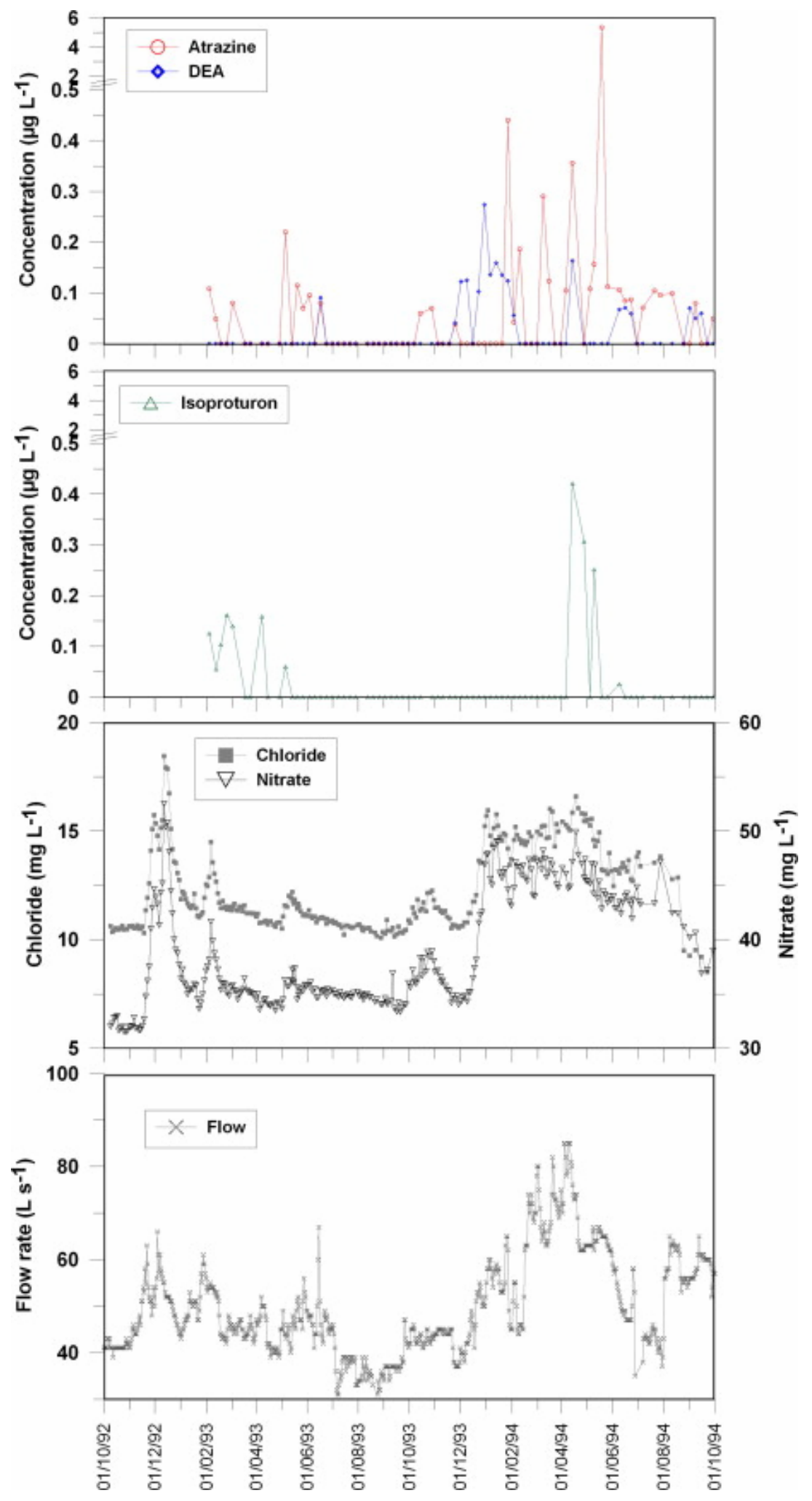

Figure 4. Focus on time series of atrazine, deethylatrazine (DEA), isoproturon, chloride and nitrate and flow rate at the Trois Fontaines spring from October 1992 till October 1994. (Pesticide concentrations below the quantification limit are represented equal to 0 .) 


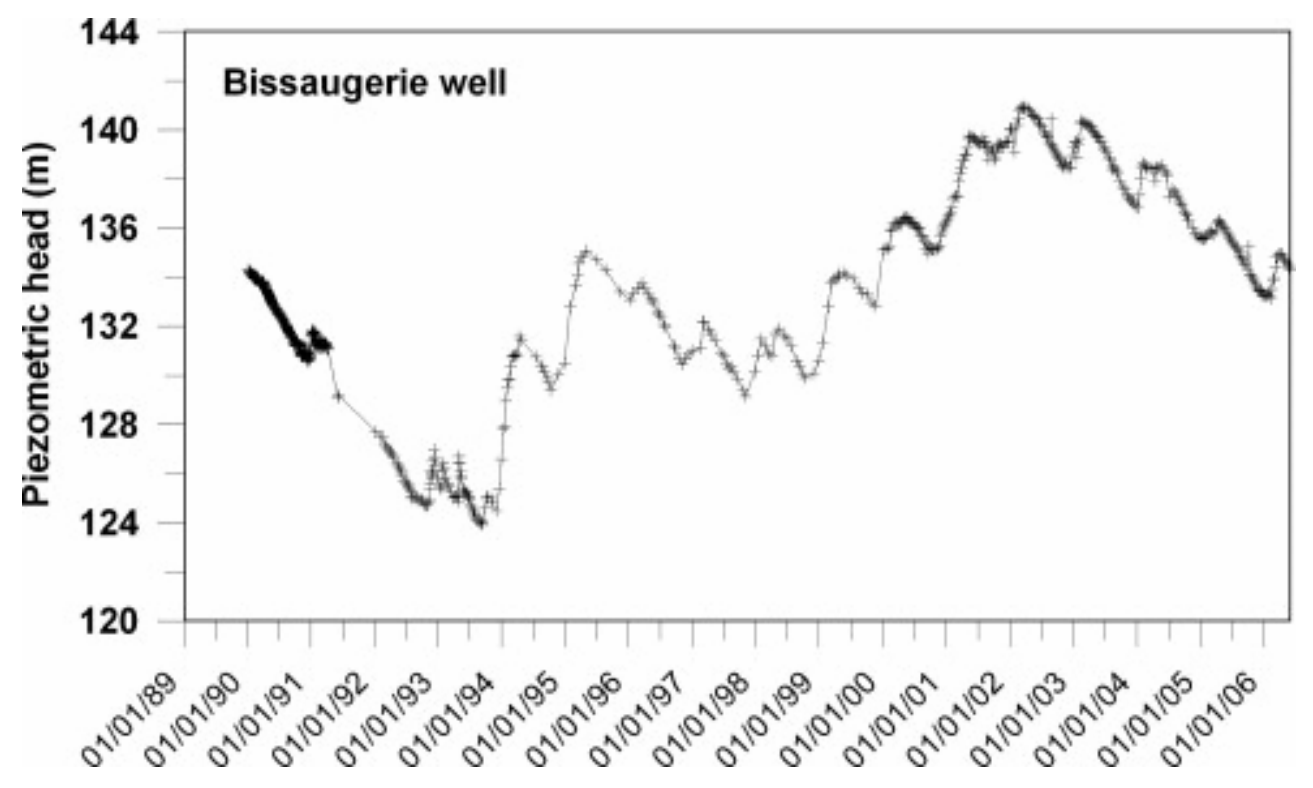

Figure 5. Variation of piezometric head at the Bissaugerie well from January 1989 till May 2006.

\section{Tables}

Table 1. : Properties of the studied pesticides and their metabolites (adapted from Footprint, 2006)

\begin{tabular}{|c|c|c|c|c|c|c|}
\hline $\begin{array}{l}\text { Common } \\
\text { name }\end{array}$ & Group & $\begin{array}{l}\text { Molecular } \\
\text { weight (g) }\end{array}$ & $\begin{array}{l}K_{\text {ow }} \\
(\mathrm{pH} 7 ; \\
\left.20^{\circ} \mathrm{C}\right)\end{array}$ & $\begin{array}{l}\text { Solubility } \\
\left(\mathrm{mg} \mathrm{L}^{-1}-\right. \\
\left.20^{\circ} \mathrm{C}\right)\end{array}$ & $\begin{array}{l}\text { Henry law } \\
\text { constant } \\
\left(\mathrm{Pa} \mathrm{m}^{3} \mathrm{~mol}^{-1}\right)\end{array}$ & $\begin{array}{l}\text { Vapour } \\
\text { pressure } \\
(\mathrm{mPa}- \\
\left.25^{\circ} \mathrm{C}\right)\end{array}$ \\
\hline Atrazine & Triazine & 215.7 & 2.7 & 35 & $1.50 \times 10^{-4}$ & $4 \times 10^{-2}$ \\
\hline DEA & Metabolite & 187.6 & 1.51 & 3200 & $1.55 \times 10^{-4}$ & 12.44 \\
\hline DIA & Metabolite & 173.6 & 1.15 & 670 & $1.52 \times 10^{-5}$ & nd \\
\hline Isoproturon & $\begin{array}{l}\text { Phenyl } \\
\text { urea }\end{array}$ & 206.3 & 2.5 & 70.2 & $1.46 \times 10^{-5}$ & $5.55 \times 10^{-3}$ \\
\hline MDIPU & Metabolite & 192.3 & nd & nd & nd & nd \\
\hline DDIPU & Metabolite & 178.2 & nd & nd & nd & nd \\
\hline
\end{tabular}

nd: No data available. 